This Journal is available in Telkom University online Journals

Jurnal Manajemen Indonesia

\title{
Implementation of Multi-criteria Moving Average Crossover Indicators as the basis for Technical Analysis Decision Making at the Futures Exchange
}

\author{
Zian Ibnu Zain Al Abidin Al Bahsan ${ }^{1}$, Karmilasari², \\ ${ }^{1}$ Sis temInformasiBisnis, Magister ManajemenSistemInformasi, Universitas Gunadarma, Depok, Indonesia \\ ${ }^{2}$ SistemInformasiBisnis, Magister ManajemenSistemInformasi, Universitas Gunadarma, Depok, Indonesia
}

\begin{abstract}
The purpose of this paper is to minimize the risk of trading option and futures through conducting technical analysis utilizing Double Crossover Method. Hence, it tries to seek the answer on some problems such as: foreign exchange tradingwithout having to make official and uncomplicated investments, trading without having to spend a lot of time, testing double crossover methods in a short time, and how to determine the most effective double crossover methods with multi-criteria considerations. Four methods were used which included the review, pre-testing, testing, and drawing conclusions. Based on the results of these stages, it was found that MT4 FXDD, SMA 5 - 10 pairs on H4 Timeframes, Expert Advisors, and Backtesting were the answers to the existing problems. Based on the aforementioned results, there are some suggestion for general investors, this strategies support their activities on getting real and efficient foreign exchange trading facilities without Joining procedural and official investments in the futures exchange; utilizing efficient decision makers tools in trading to avoid or minimize the loss, applying the most effective Double Crossover Method priority used as a technical analysis in trading foreign exchange based on test results. At last, this study explains the application of the double crossover method, which is a method that utilizes two moving average lines to generate a more effective and accurate trading signal for making decision and minimizes losses compared to the use of a single moving average.
\end{abstract}

Keywords-F31 Foreign Exchange; G13 Futures Pricing; F17 Trade Forecasting and Simulation; E22 Investment.

\begin{abstract}
Abstrak
Tujuan dari artikel ini yaitu untuk meminimalkan risiko trading option and futures melalui penggunaan analis is teknis dengan menggunakan Metode Double Crossover. Oleh karena itu, penelitian ini mencoba mencari jawaban pada beberapa masalah terkait dengan hal berikut yaitu: bagaimana melakukan perdagangan valuta asing tanpa harus melakukan investasi resmi dan tidak rumit, bagaimana melakukan perdagangan tanpa harus menghabiskan banyak waktu, bagaimana menguji metode Double Crossover dalam waktu singkat, dan bagaimana menentukan metode Double Crossoveryang paling efektif dengan pertimbangan multi-kriteria. Empat metode digunakan yang meliputi tinjauan, pra-pengujian, pengujian, dan menarik kesimpulan. Berdasarkan hasil dari tahap-tahap ini, ditemukan bahwa jawaban dari masalah yang dicari dalam penelitian ini secara berurutan yaitu menggunakanaplikasi MT4 FXDD, SMA 5 - 10 pasang pada H4 Timeframes, Expert Advisors, dan Backtesting adalah. Berdasrakan hasil diatas, ada beberapa saran bagi investor atau masyarakat umum, strategi ini mendukung kegiatan mereka dalam mendapatkan fasilitas perdagangan valuta asing yang nyata dan efisien tanpa bergabung dengan investasi resmi dan penuh prosedural di bursa berjangka; Memanfaatkan alat pembuat keputusan yang efisien dalam perdagang an untuk menghindari atau meminimalkan kerugian, menerapkan prioritas Metode Double Crossover paling efektif yang digunakan sebagai analis is teknis dalam perdagangan valuta asing berdasarkan hasil tes. Nilai terpenting dari penelitian ini menjelaskan penggunaan metode double crossover, yaitu metode yang memanfaatkan dua garis moving average untuk menghasilkan sinyal perdagangan yang lebih efektif dan akurat dalam pengambilan keputusan dan meminimalkan kerugian dibandingkan dengan penggunaan single moving average.
\end{abstract}

Kata Kunci_- Valuta Asing (F31); Harga Saham (G13); Perkiraan dan Simulasi Perdagangan (F17); Investasi (E22).

\section{Article info}

Received (29th November, 2018)

Revised (28 ${ }^{\text {th }}$ December, 2018)

Accepted (4 $4^{\text {th }}$ February, 2019)

Corresponding_author:zabjianibnu@gmail.com 


\section{INTRODUCTION}

Investments in financial assets in the money market, for example in the form of certificates of deposit, commercial paper, money market securities, and others (Abdul, 2005).Investment is an activity of placing funds in productive assets in the hope of obtaining capital growth in a certain period of time. Investors are called investors. Generally investments are divided into two, namely investment in financial assets (financial assets) and investments in real assets (real assets). Investments in financial as sets are in the money market, for example in the form of certificates of deposit, commercial paper, money market securities, and others (Abdul, 2005).

Many investment choices are flourishing in Indonesia. These various investment instruments provide an opportunity for investors to choose investment instruments that are most profitable for their capital investments and risk choices that are appropriate to each investor (Ariana, 2010). For investors, futures trading activities, hereinafter are referred to as futures contracts (future contracts), can be used as investment choices that are quite attractive compared to other investments. These futures markets are better known as the Futures Exchange trading futures contracts for various commodities, such as agriculture, plantations, mining, and financial products like foreign currency (foreign exchange or forex), even indexes like stock indexes.

Foreign exchange is the largest investment business in the world beating other investment businesses. Foreign exchange is officially regulated in Indonesia as a product of the Alternative Trading System (SPA) at the Jakarta Futures Exchange. This trading system is regulated in Law Number 10 of 2011 amendments to Law Number 32 of 1997 concerning Commodity Futures Trading (JakartaFutures Exchange, 2018).In all fields of investment, the possibility of risk of unexpected losses can occur. Because basically no investment is completely free from risk. The risk of failure is in every decision making especially with the uncertainty of price movements of currencies that are constantly happening. The risks involved depend on the completeness of the information and the quality of the analysis prior to the decision making by investors to minimize the risk of loss in making decisions in this futures exchange transaction, especially in foreign exchange investments.

Foreign exchange consists of two types of analysis factors, namely fundamental analysis and technical analysis (Agus, 2017). Fundamental analysis is an analys is that utilizes issues, rumors, news, and economic data that occur in a country that is directly related to the market. Fundamental analys is is a price driving factor but it cannot stand on its own yet side by side with technical analysis.Technical analysis is an approach method based on a graph of price movements. Price changes that occur either increase or decline form a pattern. This pattern of price movements is used as material for research by a technical analyst (Poppy and Harjahdi, 2013).

Moving Averages (MA) is the most widely used indicator by technicalists because it is very easy to use and analyze. This indicator is classified in a period of short and long periods. The most commonly used periods are 5, 8, 10, 20, 25, 30, 50, 100, 120, and 200 days. According to Ong (2017), he stated that MA with short periods is more sensitive, that is faster to send signals to traders / investors, but too often send bad signals / whipsaw, while longer periods have better performance when the trending / trend continues which is effective in muffle the whipsaw but produce a slower signal so that the investor loses some of the profit that should be obtained. Because of the weakness in the MA, then to confirm or strengthen the signal is used a combination of two MA lines which are often called Double Crossover Methods.

\section{LITERATUREREVIEW}

\section{A. Commodity Futures Trading}

Based on Law Number 32 of 1997 concerning Commodity Futures Trading, futures trading is anything that is related to the sale and purchase of commodities with delivery then based on Futures Contracts and options on Futures Contracts (Bappebti, 2017).

Futures trading are conducted at the Futures Exchange, hereinafter referred to as the exchange, trading futures contracts of various commodities. The place where the Futures Contract is traded is also called the Futures Market. Thus on the exchange there will be many Futures Markets in accordance with the number of commodities traded. The prices of commodities formed on the exchange take place transparently to reflect the strength of supply and actual demand.

There are two main benefits of commodity futures trading, namely as a means of risk management through hedging and price discovery. Through hedging activities using a Futures Contract, it can reduce as little as possible the impact (risk) caused by the price fluctuation. Commodity producers can obtain price guarantees so that they are not affected by the increase / decrease in selling prices on the cash market. The second benefit is as 
a means of transparent and reasonable price formation that reflects the conditions of supply and the actual demand of traded commodities.

Futures Contract Users can be carried out by producers, processors, traders, exporters, and consumers as a tool to protect themselves from the risk of price fluctuations. The futures market promises income stability for producers because the commodity prices can be predicted and locked properly. While commodities that are the subject of futures contracts traded on the exchange are commodities of agriculture, forestry, mining, upstream industry, and services.

According to Serfianto et al. (2017), they stated that if a customer or investor wants to make a sale and purchase transaction for a Futures Contract on the Futures Exchange, then he must deposit the margin or guarantee the transaction. The transaction margin or guarantee can be in the form of money or securities placed by the customer at the Futures Broker.

\section{B. Alternative Trading System (ATS)}

\section{Definition of Alternative Trading System(ATS)}

Alternative Trading System is a trading system related to the sale and purchase of Derivative Contracts other than Sharia Futures and Derivative Contracts (Derivatives Contract in Islamic Law) which are conducted outside the Futures Exchange, bilaterally through margin withdrawals registered with the Futures Exchange and the Futures Clearing House [https://www.jfx.co.id/page/system-trading-alternative, acces sed January 31, 2018].

In trading global derivative contracts, there are many known and various products that are traded on OTC (Over the Counter). Generally customers transact directly with OTC derivative contract providers. An Alternative Trading System perfects the OTC trade, where there are organizer traders who become market makers for many parties, while customers transact through futures brokers who provide mandate delivery services

\section{Types of Alternative Trading System Products}

According to Serfianto et al. (2017), the types of contracts traded in the Alternative Trading System are as follows:

a. Foreign Exchange Derivative Contract (Foreign Cross Currency);

b. Stock Index Contract (Stock Index);

c. Futures Contract;

d. Derivatives Contract in Islamic Finance.

3. History of Alternative Trading System

Alternative Trading Systems (ATS) are accommodated because of three reasons. The first reason, ATS is an effort to improve the quality of community protection from the practice of trading derivative contracts outside the exchange that are not responsible and have harmed many of its customers.

The second reason is that the image of the derivatives trading industry is directly related to the malpractice of those unregulated brokers. Without attempting to accommodate these activities into more civilized and wellregulated a practice, the image of derivative trading is almost impossible to repair.

Third, to save the new-born futures trading industry whose birth was also driven by government initiatives from bankruptcy?

\section{Foreign Exchange Investment}

Investment in foreign exchange is often referred to as the forex business. Forex is an abbreviation of foreign exchange, in Indonesian it is often translated as foreign exchange. Forex trading transactions are always carried out in the form of currency pairs. The form is paired because the value of the currency is relatively changed against other currencies. Some are strengthened or weakened against others.

Forex transactions have high liquidity meaning that whenever they want to sell there are always parties who are ready to buy, and vice versa whenever they want to buy there are always parties who are ready to sell 24 hours a day. According to Agus (2017), there are four types of accounts in conducting forex trading, namely:

1. Cent Account. This type of account is for traders who are still in the early stages of learning trading. The amount of funds needed for deposits ranges from 1-5 USD. 
2. Micro Account. This type of account has the smallest transaction volume size for a real account, which is 0.01 lots. The amount of funds needed is 50 USD minimum. It is properly recommended to deposit around 250 USD. The size of the trading volume starts from a multiple of 0.01 lots.

3. Mini Account. This type of account with the size of the transaction volume multiples 0.1 lots where the required funds are above 1000 USD or ideally around 2500 USD. The size of the trading volume starts from multiples of 0.1 lots to 1 lot

4. Standar Account. Type of account with the size of transaction volume multiples of 1 lot, the amount of funds needed is a minimum of 10,000 USD or ideally above 25,000 USD. Trading volume starts from 1 to tens of lots. Based on Bappebti's Decree (SK) Number 99 / BAPPEBTI / Per / 11/2012 where previously only standard accounts were legalized in Indonesia, there are currently two legalized accounts, namely standard and mini (Bappebti, 2018).

\section{Metatrader}

Metatrader is a software application used by traders to access the forex broker system online. Metaquotes has made two types of Metatrader, namely Metatrader 4 (MT4) and Metatrader 5. The Metatrader 4 platform has become very popular and has become the standard of the brokerage industry. The MT4 platform was first released in 2005 and is designed specifically for forex trading, futures, and CFDs. The new MT5 was released in 2010 in accordance with the latest developments in forex technology.

Traders can trade forex easily, quickly, and equipped with sophisticated tools and facilities to analyze with the Metatrader. Almost all brokers in the world support their traders with the Metatrade trading application platform.

\section{E. Fundamental and Technical Analysis}

Forex fundamental analysis is more focused on economic factors that can affect currency price movements. Fundamental analysis is not just looking at graphs, but looking at the economy globally, so that fundamental analysis is also more suitable to be applied within a long transaction period.

Technical analysis is a method of estimating price movements by looking at historical data on the market. Price data is the type of data that is most widely used in the analysis process although there are several other types of data that are also used in the analysis process such as volume and open interest in futures contracts.

Analysts who do research using technical data are called technical analysts or are often referred to as technicalists, technicians, or chartists. Technicalists do not use economic data to measure intrinsic value as is done by fundamentalists, but use charts (charts) that record price movements and number of transactions (volumes) to identify a pattern of price movements that occur in the market (Ong, 2017).

\section{F. Moving Average}

Moving Average or MA is an indicator used by traders (Heri, 2012). Moving Average is a technical indicator that is most widely used by investors and traders around the world because of its ability to eliminate subjective factors from each analyst. From the way of calculating the average price, MA is divided into three models:

1. Simple Moving Average (SMA). SMA is a pure model of average price movements. When it is the first time using the Moving Average indicator, generally the trading terminal / Metatrader will display SMA as the first choice. The calculation is taken from the sum of all data then divided by the number of periods observed.

2. Weighted Moving Average (WMA). The WMA calculation is taken based on the division of the total number of periods. WMA is more sensitive than SMA so it produces signals faster than SMA, but has more noise and only covers a certain period. The mathematical form of WMA is formulated as follows:

$$
\text { WMA }=\frac{\sum(\text { Data } x \text { Weighted })}{\sum \text { Weighted }}
$$

3. Exponential Moving Average (EMA atau XMA). EMA or XMA is MA with more complicated calculations among the three. Exponential Moving Average is an indicator that can provide an earlier signal. But on the 
contrary, the more sensitive the calculation, the more false signals generated. In the mathematical form, the XMA or EMA is formulated as follows:

$$
X M A=\left(\frac{2}{\text { periode }+1} \times(\text { Current Price }- \text { Previous } X M A)\right)+\text { Previous } X M A
$$

\section{G. Decision Support System (DSS)}

Decision Support System (DSS) is a system that is able to provide problem solving capabilities and communication capabilities for problems with semi-structured and non-structured conditions. DSS can explain alternative choices to decision makers. Whatever and however the process, one of the most difficult further stages that decision makers will face is in terms of their application.

Analytical Hierarchy Process is a concept for making multicriteria-based decisions (many criteria). AHP becomes a method of determining / making decisions that combines the principles of subjectivity and objectivity of the makers of the Decision Support System (DSS) or its decisions (Ditdit, 2017).

Analytical Hierarchy Process (AHP) is commonly used in compiling models for simplifying problems. The advantage of AHP compared to the others is the hierarchical structure as a consequence of the selected criteria to the most detailed sub-criteria. In addition, it also takes into account the validity of the tolerance to the inconsistency of various criteria and alternatives chosen by decision makers (Achiyanur et al., 2008).

The three main stages in AHP are the creation of hierarchies, pairwise comparisons, and synthesizing decisions. At the first stage; goals, parameters (criteria), and alternative decisions must be arranged hierarchically (Ditdit, 2017). The arrangement of hierarchies or decision structures is carried out to describe the systemelements or alternative decisions identified.

In the second stage, pair-wise comparisons are carried out using numerical ratings (values 1-9) which have verbal judgment implications.

Table 1. Pairwise Comparative Fundamental Scale of AHP

\begin{tabular}{|c|c|c|}
\hline $\begin{array}{l}\text { Importance of } \\
\text { Goals }\end{array}$ & Definition & Explanation \\
\hline 1 & Equal importance & Both activities have the same contribution to goals. \\
\hline 3 & Moderate importance of one over another & Experience and values support one element than another. \\
\hline 5 & Essential or strong importance & $\begin{array}{l}\text { Experience and values strongly support one element than } \\
\text { another. }\end{array}$ \\
\hline 7 & Very strong importance & One element is supported and dominant in practical activity. \\
\hline 9 & Extreme importance & $\begin{array}{l}\text { Evidence supporting one element that has the highest values to } \\
\text { enhance. }\end{array}$ \\
\hline $2,4,6,8$ & $\begin{array}{l}\text { Intermediate values bet ween the two adjacent } \\
\text { judgments }\end{array}$ & When a compromise is needed \\
\hline Contrary & \multicolumn{2}{|c|}{ If activity $i$ gets a number $n$ compared to $j$, then $\mathrm{j}$ has $1 / \mathrm{n}$ number compared to $\mathrm{i}$} \\
\hline Ratio & The ratio obtained directly from the measurement & \\
\hline
\end{tabular}

Source: Saaty, 1990

The third stage, synthesis of priorities whose results are in the form of global priority terms to give priority weighting.This study uses two devices, namely hardware and software.

\section{RESEARCH METHODOLOGY}

This study uses two devices, namely hardware and software. Supporting hardware in building system applications in this study has minimal specifications [http://www.fxdd.com, accessed in March 2018], including: Prosesor2.0 GHz or faster CPU (support to instruction set of SSE2); Microsoft Windows XP (SP3)/2003/ Vista/2008/7/8/10;RAM 512 MB (1 GB recommended); Free hard disk space 50 MB; Screen resolution $1024 \times 768$ or higher; Modem/connection speed $36.6 \mathrm{Kbps}$ or faster.

The minimum software used in making this application is as follows: 
A. Metatrader 4 is an extraordinary trading application as a technical analysis tool and allows the use of automated trading systems (trading robots) and copy trading (Meta, 2018);

B. MetaQuotes Language 4 (MQL4) is an object-oriented high-level programming language intended to write automatic trading strategies, specific technical indicators for the analysis of various financial markets. MQL4 is based on the concept of the popular C ++ programming language (Mq14, 2018);

C. Expert Choice 11 is software that can be used for problem solving calculations with AHP. Expert Choice applications have been tested for reliability where they can make calculations up to seven levels consisting of thous ands of criteria or alternatives.

Selection of Server and Account Trading in this study uses FXDD brokers that are conducted so that MT4 can run with realtime data and can transact like a trader registered officially at a broker on the futures exchange, especially foreign exchange.

The account type selected is a demo account type. Especially in Indonesia and Asia, FXDD partners with Gain scope to serve Indonesian Traders consultants who want to trade through FXDD that is affiliated to FXDD Malta, but the parent remains FXDD USA.

The currency used is EUR / USD. EUR / USD is the most common pair traded in the foreign exchange market. The euro is the second important currency after the USD in international money and capital markets which has impressive statistics for a currency that has just circulated (Dominguez, 2006).

Moving Average (MA) is the most widely used indicator by technicalists because it is very easy to use or analyze.SMA (Simple Moving Average) which is one form of MA can provide clues about good trend and resistance support. Simple Moving Average reflects the average price of the value of a stock / foreign exchange price movement in a certain time span in a simple manner.

Methods with different periods are used to cover the weaknesses of the period where this method can confirm each other or strengthen the signal so that it can reduce whipsaw while being sensitive enough to give open and close signals. The time span of the combination used for high school in general and commonly used is high school period 5 and 10, high school period 5 and 20, high school period 8 and 120, high school period 10 and 50, high school period 20 and 50, high school period 20 and 100,20 and 200 period high schools, and 50 and 200 period high schools (Ong, 2017).

The calculation formula SMA, in SMA-5 is:

$$
S M A=\frac{\mathrm{h} 1+\mathrm{h} 2+\mathrm{h} 3+\mathrm{h} 4+\mathrm{h} 5}{5}
$$

Where: closing prices for the first day to fifth $=\mathrm{h} 1, \mathrm{~h} 2, \mathrm{~h} 3, \mathrm{~h} 4, \mathrm{~h} 5$. This parameter can be replaced by using the opening price, the highest price, and so on.

The preparation of the Trading Strategy is divided into two very decisive positions, namely:

\section{A. Open Position in trading}

Buy transactions will be carried out if the shorter period SMA cuts (cross) over the SMA for a longer period. This form of buy is often referred to as a golden cross which indicates that the market is bullish (bull market). Short transactions will be carried out if the shorter period SMA crosses down the SMA for a longer period.

B. Closed Position or Exit in trading

If the transaction is still open buy, then the close order will be done if the shorter period SMA cuts (cross) down the SMA. Longer period is the opposite so if the transaction is still open sell, then the close order will be done if the shorter period SMA cuts (cross) to over a longer period of SMA.

This research uses Forex Robot or commonly called Expert Advisors (EA). Expert Advisors (EA) are computer programs designed to trade foreign exchange automatically. This robot can open transactions and close transactions independently without human intervention.

In this test, to give a large floating (floating position / not closed) so that when executed gets a maximum profit / minus profit that is minimal, then the function strategy of outstaying the losses is activated or the status of close losses is no. so the strategy will choose not to close unfavorable trading with the opposite signal, but open a new open position. Stop loss order from this unprofitable trade is moved to the opening price. 


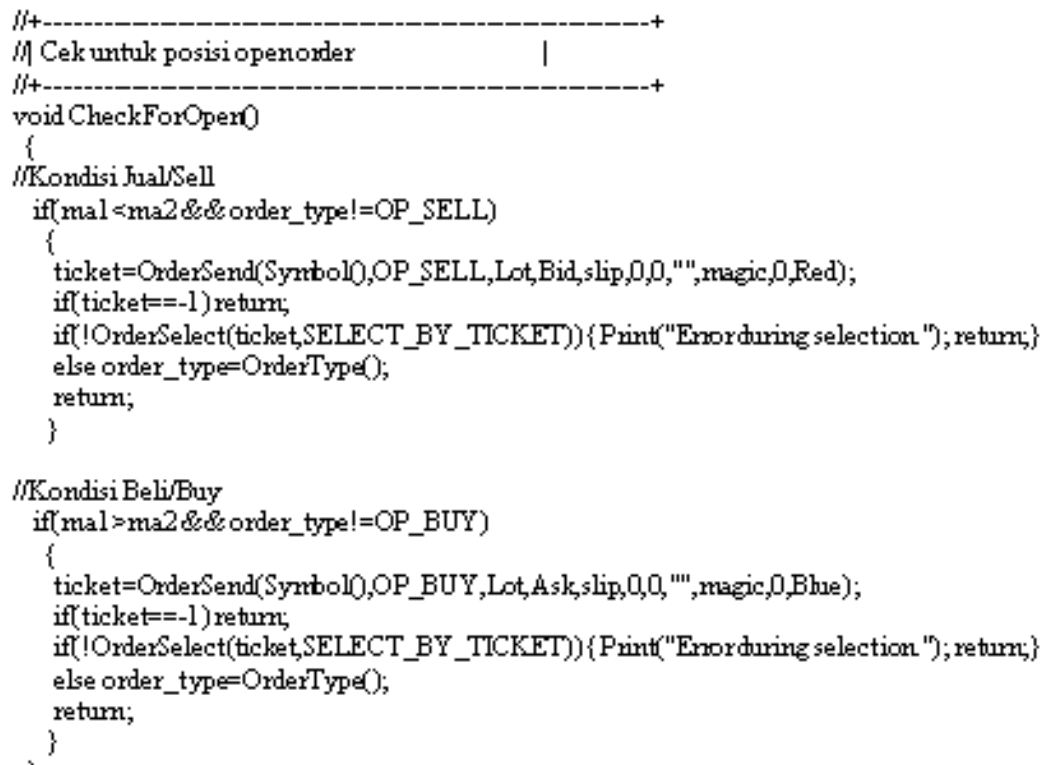

Fig. 1.Open Position Code

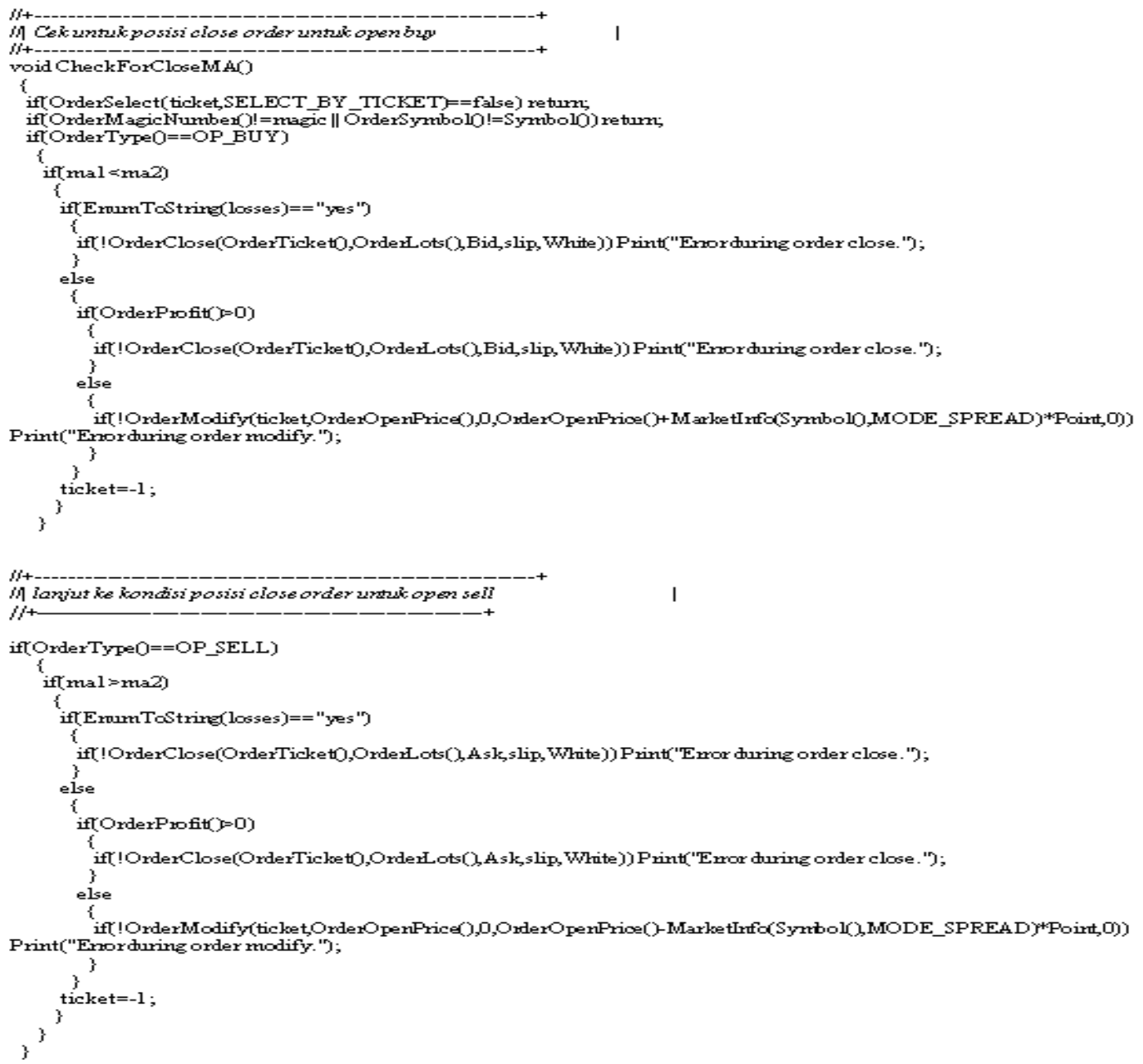

Fig. 2.Closed Position Code 
Selection of Test Method in this study consisted of Backtesting and Analytical Hierarchy Process (AHP). Backtesting Tester Strategy is used to test the Expert Advisor that has been made. One of the advantages of doing Backtesting is that you can try a trading strategy faster than forward testing. While AHP is used to test the consistency of the results of data processing so as to produce decisions that are close to valid.

For the right trading time frame selection, it must be adjusted to the trading strategy used. If using a price action is chosen as trading strategy, a valid signal usually appears on a large time frame. Signals on large / high time frames reflect fairly clear market sentiments, whereas on small / low time frames sentiment tends to change. The time frame used / selected for the EA test is the H4 Timeframe which can guarantee against a valid signal compared to Timeframe with other smaller periods.

The testing data used is the EUR / USD price movement data for the last two years, starting from the beginning of 2016 until the end of 2017 which is displayed in the form of a chart in the form of candlesticks. Test objectives along with the criteria and alternatives as the direction of the test process carried out are illustrated by the decision structure or hierarchy as follows.

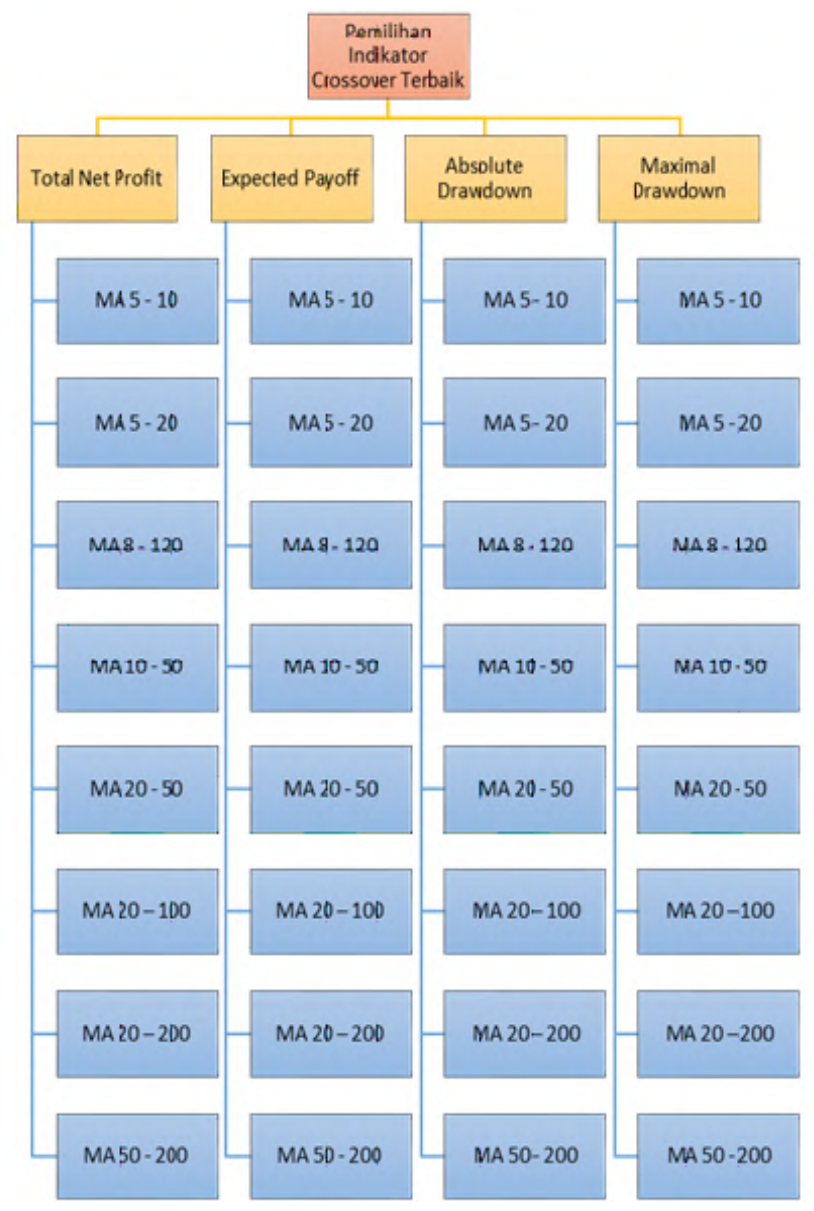

Fig. 3. AHP hierarchy in Indicator Selection Decision Making

Where:

1. Total Net Profit equals to Gross Profit minus Gross Loss;

2. Profit Factor equals to ratio from Gross Profit and Gross Loss);

3. Absolute Drawdown value is a value that shows the difference between initial deposit / initial capital and the smallest value of equity that occurs during trading;

4. Maximal Drawdown is the biggest difference taken from the difference between the highest equity profit and the smallest equity loss during the entire trading. 
To determine the intensity of the influence of various components of a system, it must be done with a kind of measurement on a scale with units of pounds, seconds, miles and dollars. But such scales limit the nature of ideas that can be handled. Social, political and qualitative factors cannot be reasonably estimated by physical or economic measurements (Saaty, 1993).

In the four existing criteria: Total Net Profit, Expected Payoff, Absolute Drawdown, and Maximal Drawdown for the data can be determined according to Table 2 with a pairwise comparison / pairwise matrix.

Table 2.. Data in Paired Comparison Matrix - Criteria

\begin{tabular}{ccccc}
\hline Criteria & Total Net Profit & Expected Payoff & Absolute Drawdown & Maximal Drawdown \\
\hline Total Net Profit & $1 / 1$ & $2 / 1$ & $4 / 1$ & $3 / 1$ \\
Expected Payoff & $1 / 2$ & $1 / 1$ & $3 / 1$ & $2 / 1$ \\
Absolute Drawdown & $1 / 4$ & $1 / 3$ & $1 / 1$ & $1 / 2$ \\
Maximal Drawdown & $1 / 3$ & $1 / 2$ & $2 / 1$ & $1 / 1$ \\
\hline
\end{tabular}

Where:

Elemen A:Extreme -------------- Equal ----------------Extreme

Elemen A: 9 - 75 3-1- 357 - 9 :Elemen B

1. Total Net Profit 2x (between equal and moderate) is more important than Absolute Drawdown;

2. Total Net Profit $4 \mathrm{x}$ (between moderate and strong) is more important than Absolute Drawdown;

3. Total Net Profit 3x (moderate) is more important than Maximal Drawdown;

4. Expected Payoff 3x (moderate) is more important than Absolute Drawdown;

5. Expected Payoff 2x (between equal and moderate) is more important than Maximal Drawdown;

6. Maximal Drawdown 2x (between equal and moderate) is more important than Absolute Drawdown.

\section{RESULT AND DISCUSSION}

Based on the results of EA processing and the results of the H4 Timeframe data can be described in accordance with Table 3 below.

Table 3. Comparis on of Backtesting Test Results in Timeframe H4

\begin{tabular}{ccccc}
\hline $\begin{array}{c}\text { Double } \\
\text { Crossover }\end{array}$ & $\begin{array}{c}\text { Total Net } \\
\text { Profit }\end{array}$ & $\begin{array}{c}\text { Expected } \\
\text { Payoff }\end{array}$ & $\begin{array}{c}\text { Absolute } \\
\text { Drawdown }\end{array}$ & $\begin{array}{c}\text { Maximal } \\
\text { Drawdown }\end{array}$ \\
\hline MA 5 and 10 & 421.46 & 2.00 & 21.57 & 283.14 \\
MA 5 and 20 & 11.22 & 0.08 & 32.60 & 343.10 \\
MA 8 and 120 & -169.69 & -2.29 & 185.39 & 217.23 \\
MA 10 and 50 & -62.96 & -0.83 & 136.86 & 348.24 \\
MA 20 and 50 & 129.62 & 1.78 & 66.33 & 182.69 \\
MA 20 and 100 & -163.36 & -2.97 & 224.51 & 291.77 \\
MA 20 and 200 & 43.52 & 1.24 & 53.27 & 72.77 \\
MA 50 and 200 & 57.66 & 2.31 & 79.44 & 88.82 \\
\hline
\end{tabular}

Based on the comparison of the test results table, it was found that the largest Total Net Profit was obtained from the Double Crossover Method 5 and $10 \mathrm{MA}$, while the 8 and $120 \mathrm{MA}$ were in the smallest order. To Expected Payoff here, MA 50 and 200 are the most promising benefits, meaning that every time trading is done, it will get a profit of $\$ 2.31$, while the 20 and 100 MAs are in the least promising order for each trade where 
each transaction will result in loss, which is amounting to $-\$ 2.97$.

In Absolute Drawdown the smaller the value, the smaller the risk of floating due to loss. MA 5 and 10 show the best, while MA 20 and 100 are the most risky. This is due to the fact that before the first profit is obtained, there is a floating loss of 224.51 (you can imagine that there is little free margin that will result in call margins).

Maximal Darwdown is the biggest floating hill difference from the peak floating profit that occurs with the deepest valley of floating loss afterwards before another floating hill occurs. The greater the Drawdown, the greater the floating equity risk that occurs. The 20 and 200 MA pairs are the best and most effective in applying the trading strategy, this is indicated by the smallest Maximal Drawdown value, while the 10 and 50 MA pairs are the most at risk among the five existing Double Crossover Methods. Based on Table 1.3, the weighting is shown as in Table 4.

Table 4. Weighting Backtesting Test Results in Timeframe H4

\begin{tabular}{ccccc}
\hline Double Crossover & $\begin{array}{c}\text { Total Net } \\
\text { Profit }\end{array}$ & $\begin{array}{c}\text { Expected } \\
\text { Payoff }\end{array}$ & $\begin{array}{c}\text { Absolute } \\
\text { Drawdown }\end{array}$ & $\begin{array}{c}\text { Maximal } \\
\text { Drawdown }\end{array}$ \\
\hline MA 5 and 10 & 8 & 7 & 8 & 4 \\
MA 5 and 20 & 4 & 4 & 7 & 2 \\
MA 8 and 120 & 1 & 2 & 2 & 5 \\
MA 10 and 50 & 3 & 3 & 3 & 1 \\
MA 20 and 50 & 7 & 6 & 5 & 6 \\
MA 20 and 100 & 2 & 1 & 1 & 3 \\
MA 20 and 200 & 5 & 5 & 6 & 8 \\
MA 50 and 200 & 6 & 8 & 4 & 7 \\
\hline
\end{tabular}

Based on Table 1.4 , the maximu m expected payoff will be withdrawn on MA 50 and 200, while the minimum expected payoff will be gotten on MA 20 and 100. Further, maximum total net profit will be on MA 5 and 10, reversely the minimum total net profit will be on MA 8 and 120 .

Comprehensive Synthes is of Considerations and Priorities

\section{A. Criteria}

Before synthesizing the considerations that have been made, pairwise comparis on is carried out. Then the decimal value of the comparison matrix results can be seen in Table 5.

Table 5. Pairwise Comparison Matrix on Decimal Criteria

\begin{tabular}{ccccc}
\hline Criteria & Total Net Profit & Expected Payoff & $\begin{array}{l}\text { Absolute } \\
\text { Drawdown }\end{array}$ & $\begin{array}{c}\text { Maximal } \\
\text { Drawdown }\end{array}$ \\
\hline Total Net Profit & 1 & 2 & 4 & 3 \\
Expected Payoff & 0,5 & 1 & 3 & 2 \\
$\begin{array}{c}\text { Absolute } \\
\text { Drawdown } \\
\text { Maximal } \\
\text { Drawdown }\end{array}$ & 0,25 & 0,333 & 1 & 0,5 \\
Total Matriks & 0,333 & 0,5 & 2 & 1 \\
\hline
\end{tabular}

Each decimal value is divided by total matrix where this step aims to find the Eigen Vector (EV). The calculation results are illustrated in Table 6 . 
Table 6. Normalization and Eigen Vector (EV) on Criteria

\begin{tabular}{|c|c|c|c|c|c|c|c|}
\hline \multicolumn{7}{|c|}{ Normalization } & \multirow[b]{2}{*}{$\begin{array}{c}\text { Conclusion } \\
\text { of Criteria } \\
\text { Priority }\end{array}$} \\
\hline & $\begin{array}{l}\text { Total Net } \\
\text { Profit }\end{array}$ & $\begin{array}{l}\text { Expected } \\
\text { Payoff }\end{array}$ & $\begin{array}{c}\text { Absolute } \\
\text { Drawdown }\end{array}$ & $\begin{array}{c}\text { Maximal } \\
\text { Drawdown }\end{array}$ & Total 2 & $\begin{array}{c}\text { Vektor } \\
\text { Eigen }= \\
\text { (Total } \\
\text { 2/Total } \\
\text { Criteria) }\end{array}$ & \\
\hline $\begin{array}{c}\text { Total Net } \\
\text { Profit }\end{array}$ & 0,48 & 0,522 & 0,4 & 0,462 & 1,863 & 0,466 & Priority 1 \\
\hline $\begin{array}{c}\text { Expected } \\
\text { Payoff }\end{array}$ & 0,24 & 0,261 & 0,3 & 0,308 & 1,109 & 0,277 & Priority 2 \\
\hline $\begin{array}{l}\text { Absolute } \\
\text { Drawdown }\end{array}$ & 0,12 & 0,087 & 0,1 & 0,077 & 0,384 & 0,096 & Priority 4 \\
\hline $\begin{array}{l}\text { Maximal } \\
\text { Drawdown }\end{array}$ & 0,16 & 0,13 & 0,2 & 0,154 & 0,644 & 0,161 & Priority 3 \\
\hline Total 1 & 1 & 1 & 1 & 1 & 4 & 1 & \\
\hline
\end{tabular}

Calculations to get Consistency Ratio (RK or CR) where the Consistency Ratio is the result of a comparison of the Consistency Index with the Consistency Random Index which is conducted to determine the tolerance of the comparis on matrix whether it is still tolerated or not. The Table 7 below shows the biggest lambda maximum or eigen on criteria.

Table 7. Biggest Lambda Maximum or Eigen on Criteria

\begin{tabular}{cccc}
\hline & EV & Total Matrix & $\begin{array}{c}\text { EV x Total } \\
\text { Matrix }\end{array}$ \\
\hline $\begin{array}{c}\text { Total Net } \\
\text { Profit } \\
\text { Expected } \\
\text { Payoff }\end{array}$ & 0,466 & 2,083 & 0,97 \\
$\begin{array}{c}\text { Absolute } \\
\text { Drawdown } \\
\text { Maximal } \\
\text { Drawdown }\end{array}$ & 0,277 & 3,833 & 1,062 \\
\hline
\end{tabular}

CI $=(\lambda$ maks $-n) /(n-1)=(4,039-4) /(4-1)=0,013$

$\mathrm{CR}=\mathrm{CI} / \mathrm{RI}$, RI value for $\mathrm{n}=4$ is 0.90 (according to the random index value ruleconsistency).

$\mathrm{CR}=0,014$

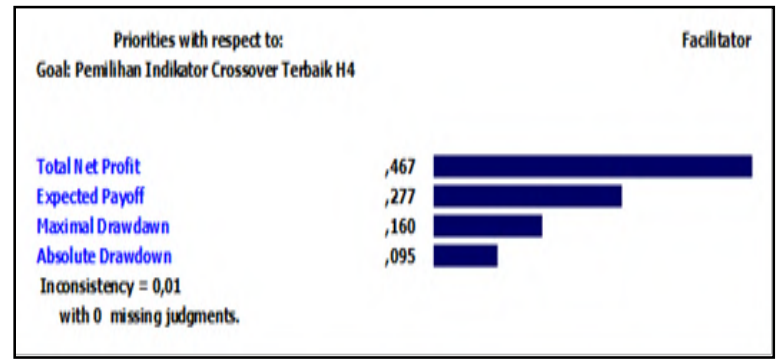

Fig. 4 Eigen Vector and Consistency Ratio Criteria 
Figure 4 can be explained that for criteria, Total Net Profit is the first priority criteria, Expected Payoff occupies the second priority criteria, Maximal Drawdown is in the third priority order, and the last is Absolute Drawdown.

That with a Consistency Ratio $(\mathrm{CR})=0.014$, this value is $\leq 0.10$, meaning that it shows consistency of the comparis on matrix so that the consistency of the existing criteria is very tolerable.

\section{B. AlternativeofTimeframe $\mathrm{H} 4$}

1. Total Net Profit

Test the consistency of the comparis ons that have been determined as follows :

Table 8. Maximum Lambda in Total Net Profit H4 Alternatives

\begin{tabular}{cccc}
\hline Total Net Profit & EV & $\begin{array}{c}\text { Total } \\
\text { Matrix }\end{array}$ & $\begin{array}{c}\text { EV x } \\
\text { Total } \\
\text { Matrix }\end{array}$ \\
\hline MA 5 and 10 & 0,222 & 4,5 & 1 \\
MA 5 and 20 & 0,111 & 9 & 1 \\
MA 8 and 120 & 0,028 & 36 & 1 \\
MA 10 and 50 & 0,083 & 12 & 1 \\
MA 20 and 50 & 0,194 & 5,143 & 1 \\
MA 20 and 100 & 0,056 & 18 & 1 \\
MA 20 and 200 & 0,139 & 7,2 & 1 \\
MA 50 and 200 & 0,167 & 6 & 1 \\
& $\boldsymbol{\lambda}$ maks $=$ & & 8 \\
\hline
\end{tabular}

Basen on Table 8 above, the maximum eigen vector is resulted by MA 5 and 10, while the minimum eigen vector is resulted by MA 8 and 120. Further, the maximum total matrix is generated by MA 8 and 120 and the minimum total matrix is generated by MA 5 and 10. The comparison of total eigen vector is displayed on the Fig. 5 as follows.

$$
\mathrm{CI} \quad=(\lambda \text { maks }-\mathrm{n}) /(\mathrm{n}-1)=(8-8) /(8-1)=0, \text { as } \mathrm{CR}=0
$$

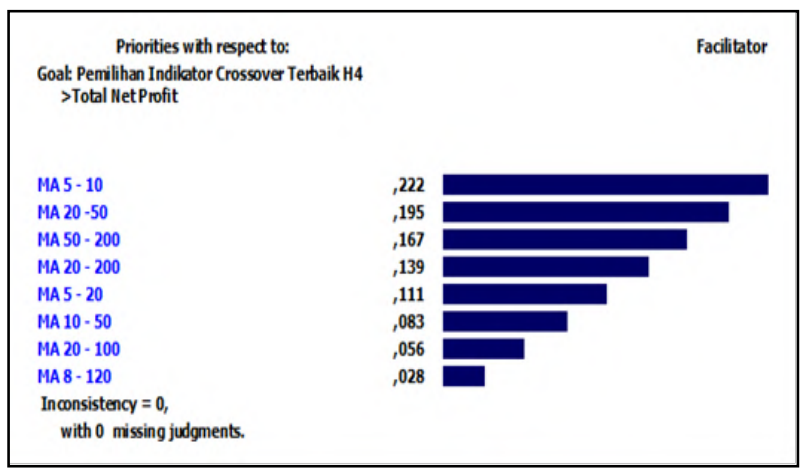

Fig 5. Eigen Vector and Consistency Ratios Total Net Alternatives Profit H4

2. Expected Payoff

The pairwise comparison matrix on expected payoff is presented on the following figure as follows. 


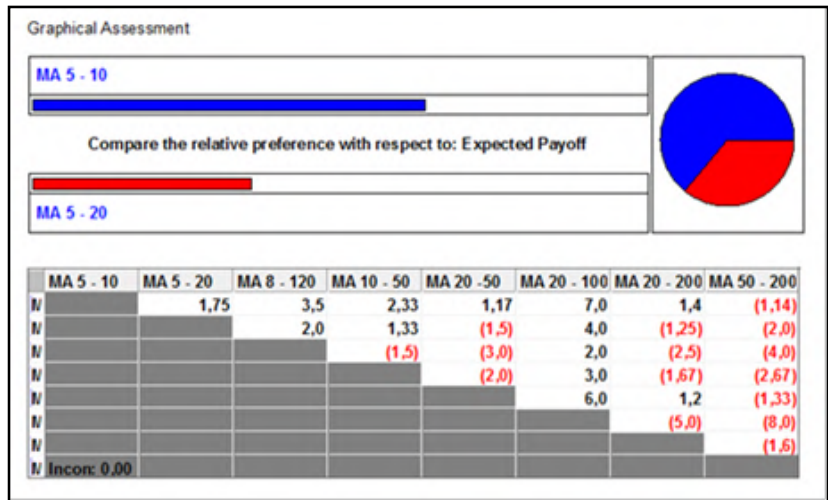

Fig 6. Pairwise Comparison Matrix on Expected Payoff Alternatives

Based on the pairwise comparison matrix on expected payoff above, the Consistency and priority of alternatives in the Expected Payoff are generated as follows:

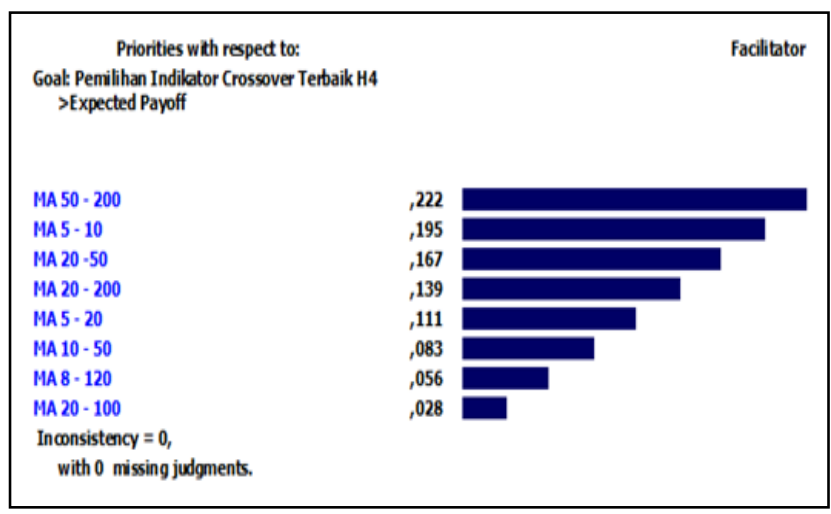

Fig 7. Eigen Vector and Consistency Ratio Expected Payoff Alternative H4

Consistency ratio $=0$, this shows the consistency of the comparison matrix in the alternative-criteria Expected Payoff.

\section{Absolute Drawdown}

The absolute drawdown is experienced when the consistency test for the predetermined comparison is conducted as follows:

Table 9. Maximum Lambda in H4 Absolute Drawdown Alternatives

\begin{tabular}{cccc}
\hline $\begin{array}{c}\text { Expected } \\
\text { Payoff }\end{array}$ & EV & $\begin{array}{c}\text { Total } \\
\text { Matriks }\end{array}$ & $\begin{array}{c}\text { EV x Total } \\
\text { Matriks }\end{array}$ \\
\hline MA 5 and 10 & 0,194 & 5,143 & 1 \\
MA 5 and 20 & 0,111 & 9 & 1 \\
MA 8 and 120 & 0,056 & 18 & 1 \\
MA 10 and 50 & 0,083 & 12 & 1 \\
MA 20 and 50 & 0,167 & 6 & 1 \\
MA 20 and 100 & 0,028 & 36 & 1 \\
MA 20 and 200 & 0,139 & 7,2 & 1 \\
MA 50 and 200 & 0,222 & 4,5 & 1 \\
& & $\lambda$ maks $=$ & 8
\end{tabular}

Based on the table above, it shows the maximum expected pay off on the absolute drawdown is on MA 50 and 200. While the minimum expected pay off is on MA 20 and 100. The comparison of the result on Table 1.9 above can be displayed on the Fig 8 as follows.

$\mathrm{CI}=(\lambda \operatorname{maks}-\mathrm{n}) /(\mathrm{n}-1)=(8-8) /(8-1)=0$, as $\mathrm{CR}=0$ 


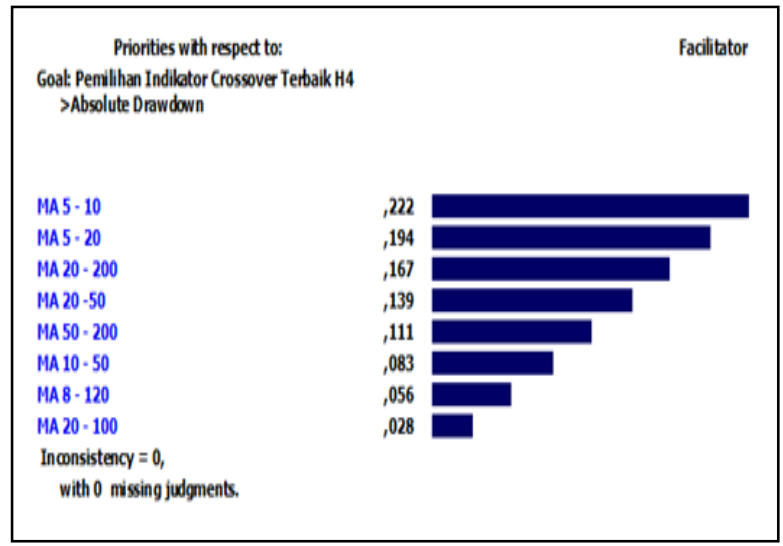

Fig 8. Eigen Vector and Consistency Alternative-Criteria AbsoluteDrawdown H4

4. Maximal Drawdown

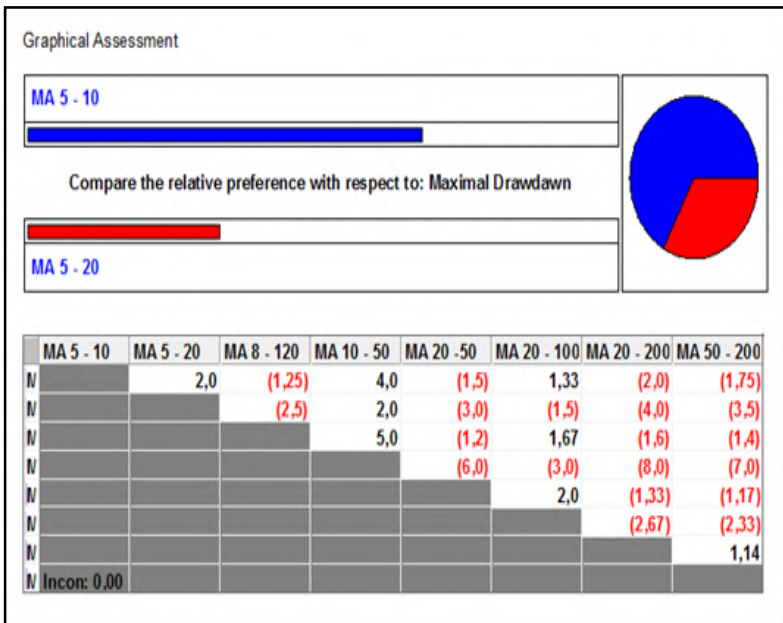

Fig 9. Pairwise Comparis on Matrix in Maximal Drawdown Alternatives

Based on the table above, it shows the maximum expected pay off on the maximal drawdown is on MA 5 and 10. While the minimum expected pay off is on MA 5 and 20. The Consistency and priority of alternatives in the Maximal Drawdown criteria are generated and displayed as follows.

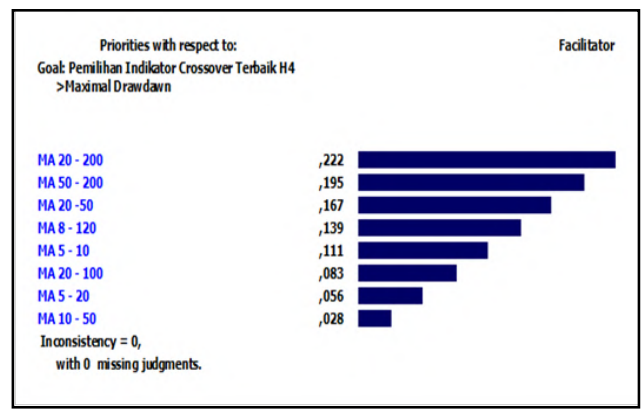

Fig 10. Eigen Vector and Alternative-Criteria Maximal Drawdown of H4 Consistency Ratio

Consistency ratio $=0$, the consistency of the comparis on matrix in the Maximal Drawdown alternative-criteria is undoubted.

Next, sorting from Composite Weight is the biggest to the smallest so that overall priority is obtained for Timeframe H4. This sorting can be displayed on the following table 10. 
Table 10. Composite Weight Order of Alternative Timeframe H4

\begin{tabular}{cccc}
\hline Alternative & $\begin{array}{c}\text { Composite } \\
\text { Weight }\end{array}$ & In Percent & Priority \\
\hline MA 5 and 10 & 0,1966272 & $19,66 \%$ & 1 \\
MA 5 and 20 & 0,1101603 & $11,02 \%$ & 5 \\
MA 8 and 120 & 0,0560387 & $5,60 \%$ & 7 \\
MA 10 and 50 & 0,074385 & $7,44 \%$ & 6 \\
MA 20 and 50 & 0,1769403 & $17,69 \%$ & 3 \\
MA 20 and 100 & 0,0496656 & $4,97 \%$ & 8 \\
MA 20 and 200 & 0,1549772 & $15,50 \%$ & 4 \\
MA 50 and 200 & 0,1812059 & $18,12 \%$ & 2 \\
Total & & $100,00 \%$ & \\
\hline
\end{tabular}

Based on the result above, the highest composite weight is on MA 5 and 10. While the lowest composite weight is on MA 8 and 120. Finally, the alternative priority details based on the performance sensitivity of each criterion can be seen in Figure 11.

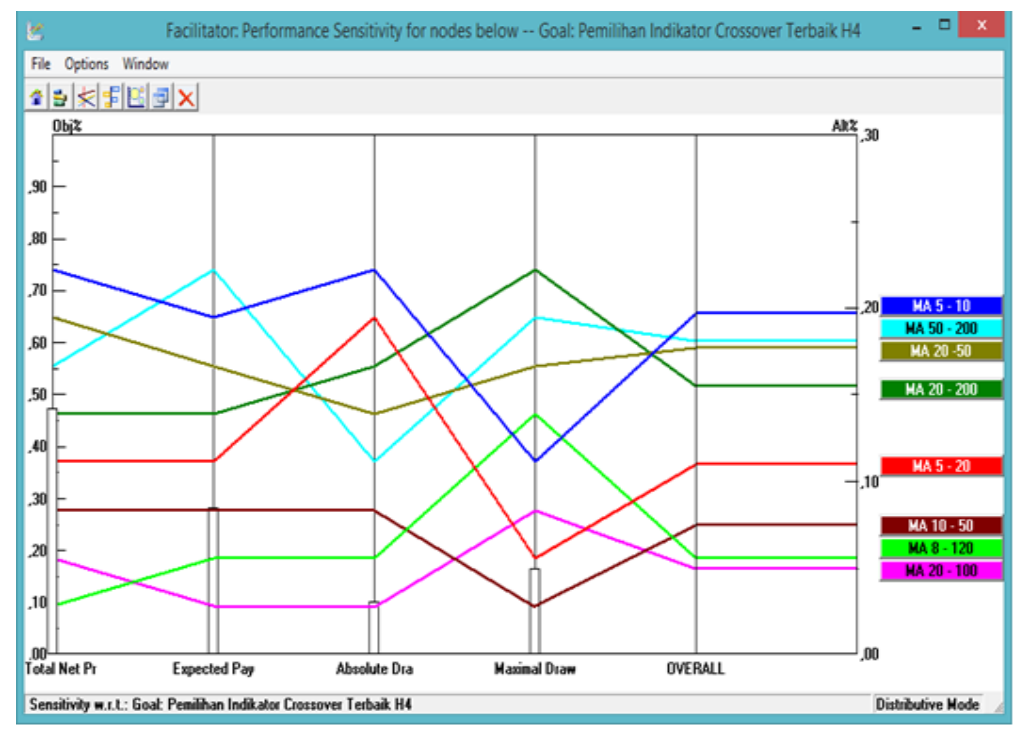

Fig 11. Performance Sensitivity for Each Node for Timeframe H4

\section{CONCLUSION}

In this digital era, investment is expected to be carried out by anyone and anywhere. Forex trading is an alternative investment that meets these requirements and can be done directly by the community because it requires simple requirements. In fact, there most investors always join the futures exchange officially and follow the rule fully procedurally before executing trading. In addition, the costs incurred by investors are mostly spent on studying the material and also depend on Expert Advisors (EAs) which require quite expensive costs. Backtesting is a solution for the Double Crossover Methods test technique that is effective to determine the performance of the EA in brief in real / real foreign exchange transactions. By applying testing of trading techniques that have been carried out using the double crossover method above, it is expected that investors can learn techniques which areconsiderably cheap, easy and very effective to provide direction for forex trading players in making decisions and minimizing losses. Hence, the capital issued by investors can be maximized in forex trading investment itself.

\section{SUGGESTION}

In future research, it is expected that there will be an assessment of the effectiveness of the double crossover method which has been done by investors community of trading forex. Further, it is necessary to develop new material that is adjusted to the upcoming trend. It is also expected that the result of study will be tested by using 
the Forward Testing test model. The use of the Double Crossover Method combined with other technical indicators such as MACD indicators, RSI, Parabolic SAR, Bollinger Bands, and others as it is expected to provide more complex support in decision making during open and closed positions.

In addition, to bring benefits to the wider community, the learning material in accordance to the techniques studied can be published through social media or forum such as Youtube, Instagram, Facebook, or Kaskus so that it will be easier to learn and reached by the community. Moreover, it needs to be socialized by conducting a meeting with forex trading investor forums directly. Furthermore, this socialization needs to be done comprehensively as today people are are really want to invest by having affordable capital with a lower level of risk.

\section{REFERENCES}

Abdul, H. (2005). Analisis Investasi edisi kedua. Salemba Empat, Jakarta.

Achiyanur, Andy, W. W., Muhammad, Y., Reza R., Zian I.ZAB, \& I Wayan S. W. (2008). Penyusunan Prioritas Produk Database yang Multikriteria Melalui Penerapan Analytical Hierarchy Process (AHP). Proceeding Seminar Ilmiah Nasional Komputer dan Sistem Intelijen(KOMMIT 2008), hal. 28-35, 20-21 Agustus 2008, Auditorium Universitas Gunadarma, Depok.

Agus, W. (2017). Investasi Valuta Asing. Andi Offset, Yogyakarta.

Ariana, M. L. (2010). Analisis Optimasi Return Portofolio pada PT. Askes Tahun 2009. Tesis, Program Pascasarjana Magis ter Manajemen, UPN Veteran, Jakarta.

Bappebti. (2017). Sekilas Tentang Perdagangan Berjangka Komoditi [Online]. http://bappebti.go.id/brosur_leaflet/detail/126 [Accessed 10 December 2017].

Bappebti. (2018). SK Kep. Kepala Bappebti [Online]. http://website.bappebti.go.id/id/regulation/decision/detail/2468.html [Accessed 13 January 2018].

Ditdit, N. U. (2017).Sistem Penunjang Keputusan: Filosofi Teori dan Implementasi. PenerbitGarudhawaca, Jakarta

Dominguez, Kathryn M. E. (2006). The European Central Bank, the Euro, and Global Financial Markets. Journal of Economic Perspectives, 20(4), Fall 2006, 67-88.

Heri, S. (2012). Cara Mudah Membuat Robot Trading Profitable Dengan EA Martiagle dan EA Scalping. PT. Elex Media Komputindo, Jakarta.

Ong, E. (2017). Technical Analysis for Mega Profit. PT Gramedia Pustaka Utama, Jakarta.

Jakarta Futures Exchange. (2018). Sistem Perdagangan Alternatif [Online]. http://jfx.co.id/page/sistemperdagangan-alternatif [Accessed 31 January 2018].

Poppy, I., \& Harjahdi. (2013). Analisis Fundamental dan Teknikal dalam Pengambilan Keputusan untuk Transaksi Emas di Perdagangan Berjangka. Jurnal Akuntansi \& Keuangan, 4(1), 55-62, Maret 2013. Universitas Bina Darma, Palembang.

Saaty, Thomas L. (1990). How to Make a Decision: The Analytic Hierarchy Process. European Journal of Operational Research, 48(1990), 9-26, North-Holland.

Saaty, Thomas L. (1993). Pengambilan Keputusan Bagi Para Pemimpin. Edisi Terjemahan, PT Gramedia, Jakarta.

Serfianto, D. P., Iswi, H.,\& Cita, Y. S. (2013).Pasar Komoditi: Perdagangan Berjangka dan Pasar Lelang Komoditi. Jogja Bangkit Publisher, Yogyakarta. 